\title{
Center Rot of Onion (Allium cepa) Caused by Pantoea ananatis Requires pepM, a Predicted Phosphonate-Related Gene
}

\author{
Jo Ann E. Asselin, Jean M. Bonasera, and Steven V. Beer ${ }^{\dagger}$ \\ Plant Pathology and Plant-Microbe Biology Section, School of Integrative Plant Sciences, Cornell University, Ithaca, NY 14853, \\ U.S.A.
}

Accepted 7 June 2018.

\begin{abstract}
Pantoea ananatis, a cause of center rot of onion, is problematic in the United States and elsewhere. The bacterium lacks disease determinants common to most other bacterial pathogens of plants. A genomic island containing the gene pepM was detected within many onion-pathogenic strains of $P$. ananatis of diverse origins. The pepM gene of $P$. ananatis putatively encodes a protein that converts phosphoenolpyruvate to phosphonopyruvate, the first step in the biosynthesis of phosphonates and related molecules. This gene appears to be essential for center rot disease. Deletion of pepM rendered the mutant strain unable to cause lesions in leaves of growing onions and water-soaking of inoculated yellow onion bulbs. Furthermore, growth of the deletion mutant in onion leaves was significantly diminished compared with wild-type bacteria, and the mutant failed to cause cell death in tobacco. Complementation of the mutated strain with pepM restored the phenotype to wild-type capability. The pepM gene is the first pathogenicity factor identified that affects bacterial fitness as well as symptom development in both leaves and bulbs in a pathogen causing center rot of onion.
\end{abstract}

Bacteria of the genus Pantoea are frequently isolated from various niches, especially plants (Walterson and Stavrinides 2015). These are gram-negative bacteria of the family Erwiniaceae (formerly belonging to the family Enterobacteriaceae) (Adeolu et al. 2016), and strains of several species within this group cause serious plant diseases. Some, such as $P$. stewartii, which causes Stewart's wilt of corn, and P. agglomerans pv. gypsophilae and pv. betae, which cause gall diseases of gypsophila or gypsophila and table beet, respectively, are known to use type III secretion systems for pathogenesis (Frederick et al. 2001; Weinthal et al. 2007). However, little is known regarding the mechanisms utilized by $P$. ananatis strains that cause center rot, a disease of onion (Allium cepa).

Strains of $P$. ananatis are currently the most-studied center rot pathogens. However, several other Pantoea species have been reported to cause center rot, including $P$. allii, $P$. agglomerans, and

${ }^{\dagger}$ Corresponding author: Steven V. Beer; E-mail: svb1@ cornell.edu

Funding: Financial support is gratefully acknowledged from the New York Onion Research and Development Program and the New York Farm Viability Institute.

*The $\boldsymbol{e}$-Xtra logo stands for "electronic extra" and indicates that five supplementary figures and one supplementary table are published online.

(c) 2018 The American Phytopathological Society
P. stewartii subsp. indologenes (Brady et al. 2011; Gitaitis and Gay 1997; Hattingh and Walters 1981; Stumpf et al. 2018). Some, but not all, strains of each species are pathogenic to onion. Analyses of genomes of several strains of $P$. ananatis revealed the absence of genes that encode type II, III, and IV secretion systems, which are common among other bacterial plant pathogens (De Maayer et al. 2014). However, quorum sensing and swimming and twitching motility have been shown as important in establishing disease in plants (Morohoshi et al. 2007; Weller-Stuart et al. 2017). Strains of $P$. ananatis typically have two or three type VI secretion systems (T6SSs), and one of these, T6SS-1, has been implicated as a pathogenicity factor for $P$. ananatis in onion leaves (Shyntum et al. 2015). Putative effectors of the T6SS have been identified by bioinformatic analyses; however, no empirical test results have been published.

Center rot of onion is characterized by lesions in growing onion leaves, rotting of stalks, and by discoloration (browning) and water-soaking of internal scales of onion bulbs (Schwartz and Mohan 2008). P. ananatis can cause serious losses, and it has been reported from many onion-growing areas of the U.S. and elsewhere (Carr et al. 2010; Gitaitis and Gay 1997; Kim et al. 2012; Schwartz and Otto 2000). Thrips have been shown to vector onion-pathogenic strains of $P$. ananatis and $P$. agglomerans (Dutta et al. 2014, 2016). Foliar lesions are often the first symptoms of disease, and these can extend through the neck into onion bulbs, resulting in bulb decay (Carr et al. 2013).

Strains of $P$. ananatis with pathogenicity to Allium species also have been described as able to cause plant cell death when infiltrated into portions of tobacco leaves (Carr et al. 2010; Kido et al. 2010). Cell death resembling the hypersensitive response (HR) was described as occurring 36 to $48 \mathrm{~h}$ after infiltration and did not appear to be a feature of strains lacking pathogenicity to the Allium species tested (Kido et al. 2010).

In this study, we identified a gene cluster that seems to be consistently present in onion-pathogenic strains of $P$. ananatis. Based on the presence of a gene predicted to encode phosphoenolpyruvate mutase (PepM), this cluster putatively encodes production of a phosphonate or phosphinate, compounds containing one or two carbon-phosphorous bonds, respectively. Deletion of the pepM gene within this cluster resulted in loss of ability to cause leaf lesions in onions, loss of ability to elicit water-soaking in inoculated onion bulbs, reductions of bacterial growth in onion leaves, and loss of the ability to cause cell death in infiltrated tobacco leaves.

\section{RESULTS}

Identification of the HiVir region.

Candidate virulence genes were chosen based on wholegenome comparisons of two onion-pathogenic and two onion- 
nonpathogenic strains of $P$. ananatis and subsequent analyses. The gene annotated as PANA_3283 in the genome of strain $P$. ananatis LMG 20103 was initially chosen as a candidate virulence gene from a contiguous cluster of 13 genes that seemed to be conserved in the two genome-sequenced onion-pathogenic strains but was absent from the two onion-nonpathogenic strains (Supplementary Fig. S1). The PANA_3283 product was annotated as a protein belonging to the major facilitator superfamily of transport proteins. This suggested that PANA_3283 would be involved in the transport of small molecules into or out of bacterial cells. The PANA_3283 64-85F/812-833R primer pair, designed to anneal within this gene, produced amplicons of the expected size from five pathogenic strains but not from four nonpathogenic strains of $P$. ananatis (Supplementary Fig. S2). An additional 21 strains of $P$. ananatis were then screened with the PANA_3283 primers. Of a total of 30 strains isolated from various hosts and geographic regions, 14 onion-pathogenic strains produced an amplicon with PANA_3283 primers, while 16 onion-nonpathogenic strains did not (Table 1). The results of this screening promoted further investigation of the gene cluster that includes PANA_3283.

Examination of the DNA sequence near PANA_3283 revealed a region (dubbed HiVir) with characteristics consistent with DNA that had been horizontally acquired. Programs designed to predict genomic islands, IslandViewer 4 (Bertelli et al. 2017) and Alien_Hunter (Vernikos and Parkhill 2006), predict genomic islands of approximately 16.5 and $20 \mathrm{~kb}$, respectively. If the boundaries of the island are called based on results from alignment in Mauve or a graph of percent GC, the island is approximately 18.1 or $18.5 \mathrm{~kb}$ in length (Supplementary
Fig. S3). HiVir has a low percentage of GC, approximately $39 \%$, compared with the whole-genome GC of $53.7 \%$, is located adjacent to a transfer RNA sequence, and contains multiple putative transposase genes. The genomic structure of the HiVir region (Fig. 1) includes a possible 10- or 11-gene operon that begins with a gene predicted to encode PepM.

Sequence comparisons of HiVir to the nucleotide and wholegenome shotgun contig databases at the National Center for Biotechnology Information (NCBI) revealed that, when present, HiVir clusters in $P$. ananatis strains are typically wellconserved, showing $100 \%$ coverage to the query sequence and greater than $99 \%$ sequence identity at the DNA sequence level. No similar DNA was found in accessions of $P$. agglomerans or $P$. allii. However, it is unclear whether any strains of those species sequenced to date are pathogenic to onions. Gene clusters with protein sequences similar to the putative HiVir 10gene operon also exist in strains of genera Xenorhabdus, Photorhabdus, and Streptomyces. However, none of the gene clusters identified with overall similarity to HiVir have been characterized in terms of phenotype or chemistry. Additional genes near the putative operon include transposase genes and other genes that might be involved in biosynthesis, alteration, or regulation of the putative HiVir product or products.

\section{Symptom development of PANA_3283 mutant bacteria in onion leaves.}

In preliminary work, the PANA_3283 gene was targeted for deletion in strain OC5a Rp ${ }^{\mathrm{r}}$. Wild type (WT), $\triangle$ PANA_3283 (a PANA_3283 deletion mutant), $\triangle$ PANA_3283 EV (a PANA_3283 deletion mutant harboring empty vector pML122), and

Table 1. Strains of Pantoea ananatis used to assess relationships between detection of PANA_3283 and pathogenicity to onion leaves

\begin{tabular}{|c|c|c|c|c|c|}
\hline CU number $\mathbf{a}^{\mathbf{a}}$ & Strain name & Source; location & Source/reference & $\begin{array}{c}\text { Leaf } \\
\text { pathogenicity }\end{array}$ & $\begin{array}{c}\text { Amplicon } \\
\text { PANA_3283 } \\
\text { primers }\end{array}$ \\
\hline 6790 & Pna 97-1 & Onion; Georgia, U.S.A. & Gitaitis and Gay 1997 & + & + \\
\hline 6822 & LMG 20103 & Eucalyptus; South Africa & De Maayer et al. 2010 & + & + \\
\hline 6829 & OC5a & Onion bulb; New York, U.S.A. & Carr et al. 2013 & + & + \\
\hline 6885 & SUPP2219 (CTB1135) & Rice; Tottori, Japan & Kido et al. 2010 & + & + \\
\hline 6853 & PA2 & Onion; Pennsylvania, U.S.A. & $\begin{array}{l}\text { E. Carr, previously } \\
\text { unpublished }\end{array}$ & + & + \\
\hline 6758 & Pans 99-9 & Prairie verbena; Georgia, U.S.A. & $\begin{array}{l}\text { R. D. Gitaitis (University } \\
\text { of GA)/Zaid et al. } 2012\end{array}$ & - & - \\
\hline 6823 & LMG 20104/BBD0003 & Eucalyptus; South Africa & Brady et al. 2008 & - & - \\
\hline 6827 & LMG 24192/R-27859/PPPPB BD442 & Maize; South Africa & Brady et al. 2008 & - & - \\
\hline 6835 & OC42 & Onion bulb; New York, U.S.A. & Carr et al. 2013 & - & - \\
\hline 6818 & ATCC 33244/LMG 2665 & Pineapple; Brazil & Adam et al. 2014 & + & + \\
\hline 6810 & R-30992/BD 640 & Maize; South Africa & Brady et al. 2008 & - & - \\
\hline 6811 & BD 647 & Maize; South Africa & Brady et al. 2008 & + & + \\
\hline 6814 & $\mathrm{R}-124715 / \mathrm{BCC} 150$ & Honeydew melon; U.S.A. & Brady et al. 2008 & - & - \\
\hline 6828 & PA4 & Onion seed; South Africa & Weller-Stuart et al. 2014 & - & - \\
\hline 6831 & OC $34 b$ & Onion; New York, U.S.A. & Carr et al. 2013 & - & - \\
\hline 6837 & OC75 & Onion; New York, U.S.A. & Carr et al. 2013 & + & + \\
\hline 6845 & OC120 & Onion, New York, U.S.A. & Carr et al. 2013 & + & + \\
\hline 6848 & OC136 & Onion, New York, U.S.A. & Carr et al. 2013 & - & - \\
\hline 6886 & Melon-1 & Melon, Japan & Kido et al. 2010 & - & - \\
\hline 6887 & SUPP1791 & Melon, Japan & Kido et al. 2010 & - & - \\
\hline 6888 & A8 & Melon, Japan & Kido et al. 2010 & - & - \\
\hline 6890 & MA-31 & Melon, Japan & Kido et al. 2010 & - & - \\
\hline 6891 & SUPP1128 & Melon, Japan & Kido et al. 2010 & - & - \\
\hline 6892 & Ajisai-9701 & Hydrangea leaf; Japan & Kido et al. 2010 & + & + \\
\hline 6893 & $\mathrm{~Pa}-5$ & Pineapple; Japan & Kido et al. 2010 & + & + \\
\hline \multirow[t]{5}{*}{6894} & Sweet corn-101 & Maize; Japan & Kido et al. 2010 & - & - \\
\hline & Cull T29 & Onion bulb; New York, U.S.A. & This work & - & - \\
\hline & Cull D72 & Onion bulb; New York, U.S.A. & This work & + & + \\
\hline & Cull I53a & Onion bulb; New York, U.S.A. & This work & + & + \\
\hline & Cull J32b & Onion bulb; New York, U.S.A. & This work & + & + \\
\hline
\end{tabular}

\footnotetext{
${ }^{a}$ CU number $=$ Cornell University culture collection unique identification number. All strains were tested and amplified with $P$. ananatis-specific primers PANA_1080 61F and PANA_1009R (Asselin et al. 2016). Partial gyrase B DNA sequence was also obtained for Cull T29, Cull D72, Cull I53a, and Cull J32b to confirm their identities as $P$. ananatis strains (Bonasera et al. 2014).
} 
$\triangle$ PANA_3283 COMP (a PANA_3283 deletion mutant harboring complementation construct pCPP1829) strains were inoculated into growing onion leaves. Lesions were measured at 2 , 4, and 6 days postinoculation (dpi). The strain used and number of days postinoculation had significant effects on lesion length. The effect of inoculation date was not significant. The interaction between days postinoculation and strain was not significant, but there was a main effect of strain and a main effect of days postinoculation. Lesion lengths from strains $P$. ananatis (Pan) OC5a $\mathrm{Rp}^{\mathrm{r}}$ WT and $\triangle$ PANA_3283 COMP did not differ significantly from each other but were significantly greater than $\triangle \mathrm{PANA} 3283$ and $\triangle$ PANA_3283 EV, which did not differ significantly from each other (Supplementary Fig. S4). For statistically significant comparisons among strains, $P$ values were 0.0013 or less. For days postinoculation, all levels (2, 4, and $6 \mathrm{dpi})$ differed significantly from each other with $P$ values of 0.0009 or less.

\section{Symptom development of pepM mutant bacteria in onion leaves.}

All onion leaves inoculated with Pan OC5a $\mathrm{Rp}^{\mathrm{r}}$ WT or pepM COMP (a pepM deletion mutant harboring complementation construct pCPP1838) developed lesions within 2 or 3 days of inoculation. Plants inoculated with $\triangle p e p M$ or $\triangle p e p M$ EV (a pepM deletion mutant harboring the empty vector) or treated with sterile water never developed lesions in three replicated experiments. At 2 dpi, leaves inoculated with WT bacteria had significantly more lesions (in 88 of 90 leaves across all reps) than leaves inoculated with $\triangle$ рерM COMP bacteria (in 80 of 90 leaves across all reps), with a $P$ value of 0.0324 (Fig. 2).

\section{Symptom development of pepM mutant bacteria in onion bulbs.}

Onion bulbs that had been inoculated with suspensions of Pan OC5a Rp ${ }^{\mathrm{r}}$ WT, $\Delta$ реpM, $\Delta$ treated with sterile water were rated for symptom severity after incubating at $28^{\circ} \mathrm{C}$ for 14 days. Symptom severity among bulbs treated with the various inocula or water fell into three significantly different groups. The percentage of the area of the cut bulb surface that appeared symptomatic was assessed, and values representing the back-transformed least squares means are given. Bulbs inoculated with WT or $\triangle p e p M$ COMP had the largest symptomatic areas (22.9 and $29.8 \%$ respectively). Bulbs inoculated with $\triangle p e p M$ or $\triangle p e p M \mathrm{EV}$ were significantly less symptomatic (2.5 and $1.3 \%$, respectively). Bulbs treated with water were least symptomatic $(0.2 \%)$. In this assay, slight browning that may have been due to wounding was not distinguishable from symptoms caused by bacteria (Figs. 3 and 4).

\section{Recovery of pepM mutant bacteria from onion leaves.}

The strain used and incubation time (days postinoculation) both significantly affected the extent of bacterial recovery. With each successive replication, the plants used were 1 week older than the previous week's group; differences in bacterial recovery among the replications of the experiment were also significant. Similar numbers of bacteria were recovered from plants inoculated with each strain immediately following inoculation ( $0 \mathrm{dpi}$ ). At $4 \mathrm{dpi}$, similar counts of bacteria were recovered from plants inoculated with Pan OC5a $\mathrm{Rp}^{\mathrm{r}} \mathrm{WT}$ and $\triangle$ рерM COMP. Significantly fewer bacteria were recovered from plants inoculated with $\triangle p e p M$ and $\triangle p e p M E V$. Recovery of bacteria from plants inoculated with all strains was significantly greater at 4 dpi than at 0 dpi (Fig. 5). For comparisons in which bacterial recoveries were considered significantly different among treatments or between times of incubation, $P$ values were $<0.0001$.

\section{Infiltration of tobacco leaves.}

Portions of leaves infiltrated with suspensions of Pan OC5a $\mathrm{Rp}^{\mathrm{r}} \mathrm{WT}$ and $\triangle$ pepM COMP developed small areas of cell death between 24 and $48 \mathrm{~h}$ following infiltration. Cell-death areas continued to enlarge in the infiltrated portions of the leaves over the course of 5 days, often spreading outside of the infiltrated area. However, leaf areas infiltrated with suspensions of $\Delta p e p M$ and $\triangle$ pepM EV strains did not exhibit cell death (Fig. 6).

\section{DISCUSSION}

Preliminary work suggested that a 16.5 - to $20-\mathrm{kb}$ region of DNA that has characteristics of horizontally acquired DNA is conserved among strains of $P$. ananatis that are pathogenic to onions. This cluster, dubbed HiVir, contains genes predicted to be involved in phosphonate biosynthesis based on the presence of the gene pepM, a hallmark of phosphonate biosynthesis ( $\mathrm{Yu}$ et al. 2013).

The product or products encoded by the putative HiVir cluster have not been characterized. Phosphonates, molecules with a single carbon-phosphorous (C-P) bond, and phosphinates, molecules with two $\mathrm{C}-\mathrm{P}$ bonds or one $\mathrm{C}-\mathrm{P}$ bond and one phosphorous-hydrogen bond, are able to mimic phosphate esters and carboxylates. This property allows these molecules to target biologically important enzymes by mimicking their substrates (Peck et al. 2012). Examples of phosphonates include herbicides (e.g., glyphosate, bialaphos), antibiotics (e.g., fosfomycin), fungicides (e.g., rhizocticins), and antiparasitics (e.g., FR900098) (Borisova et al. 2010; Eliot et al. 2008; Horsman and Zechel 2017; Nakashita et al. 1997). Numerous phosphonates have been characterized as bioactive molecules, but, to our knowledge, none have been described as pathogenicity or virulence factors active in pathogen-plant interactions.

Some clues regarding the roles of HiVir genes can be gleaned from the annotated functions of the genes within the cluster and from knowledge of characterized phosphonate biosynthetic pathways. The first biosynthetic reaction in almost all known

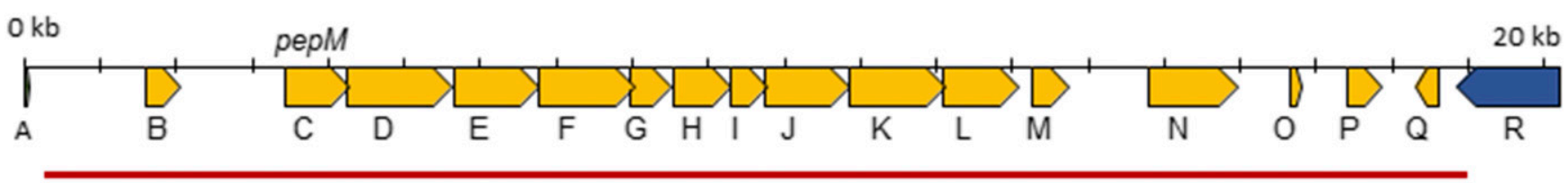

low \%GC

Fig. 1. Diagram of the HiVir region and identified genes. Genes indicated are: A, transfer RNA Phe; B, PANA_3292 (hypothetical protein); C, PANA_3291 (pepM, phosphoenolpyruvate mutase); D, PANA_3290 (yxeK, monooxygenase); E, PANA_3289 (leuA2, 2-isopropylmalate synthase); F, PANA_3288 (leuC, 3isopropylmalate dehydratase large subunit); G, PANA_3287 (leuD, 3-isopropylmalate dehydratase small subunit); H, PANA_3286 (putative methyltransferase); I, PANA_3285 ( $N$-acetyltransferase); J, PANA_3284 (ATP-grasp domain-containing protein); K, PANA_3283 (major facilitator superfamily transporter); L, PANA_3282 (hypothetical protein); M, PANA_3281 (hpaC, FMN reductase); N, PANA_3280 (carbamoyl-phosphate synthase, large subunit); O, PANA_3279 (hypothetical protein); P, PANA_3278 (insK, transposase); Q, PANA_3277 (hypothetical protein); and R, PANA_3276 (citH, major facilitator superfamily transporter). 
phosphonate biosynthetic pathways is catalyzed by PepM. That protein converts phosphoenolpyruvate to phosphonopyruvate (PnPy). However, the equilibrium of the reaction strongly favors the reverse reaction. As a result, the second step in the pathway must rapidly alter PnPy to drive biosynthesis forward. In many pathways, the second step is catalyzed by PnPy decarboxylase (Metcalf and van der Donk 2009). However, the HiVir cluster of $P$. ananatis does not include a gene encoding a putative PnPy decarboxylase. Instead, HiVir has genes similar to those encoding enzymes for the second and third steps in the biosynthesis of FR90098, an antibiotic and antimalarial phosphonate from Streptomyces rubellomurinus (Peck et al. 2012). Aside from the genes encoding the first three steps of FR90098 biosynthesis, HiVir genes are not similar to those within the FR90098 biosynthetic cluster (Supplementary Fig. S5). Therefore,
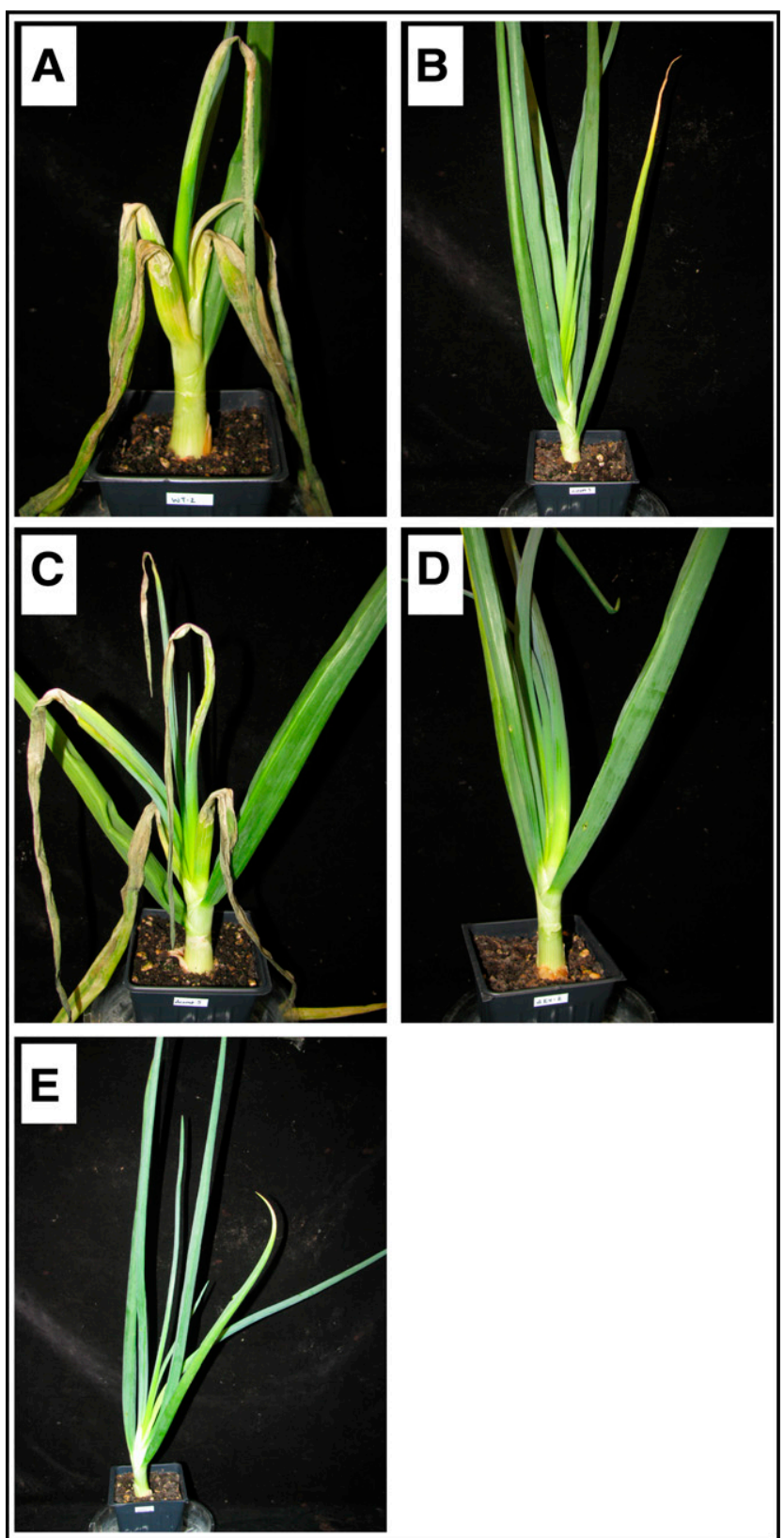

Fig. 2. Onion plants 5 days after inoculation with Pantoea ananatis OC5a $\mathrm{Rp}^{\mathrm{r}}$ wild type (WT) and derivatives. A, WT; B, $\Delta$ рерM mutant; C, $\Delta p e p M$ complemented in trans; $\mathbf{D}, \triangle p e p M$ harboring empty vector; and $\mathbf{E}$, water. Strains with functional рерм genes caused lesions in onion leaves, while those without functional pepM genes did not. it is unclear how the rest of the HiVir biosynthetic pathway might alter its product or products; this remains to be determined.

Initial work with the HiVir cluster targeted a gene predicted to encode a major facilitator superfamily protein, PANA_3283.
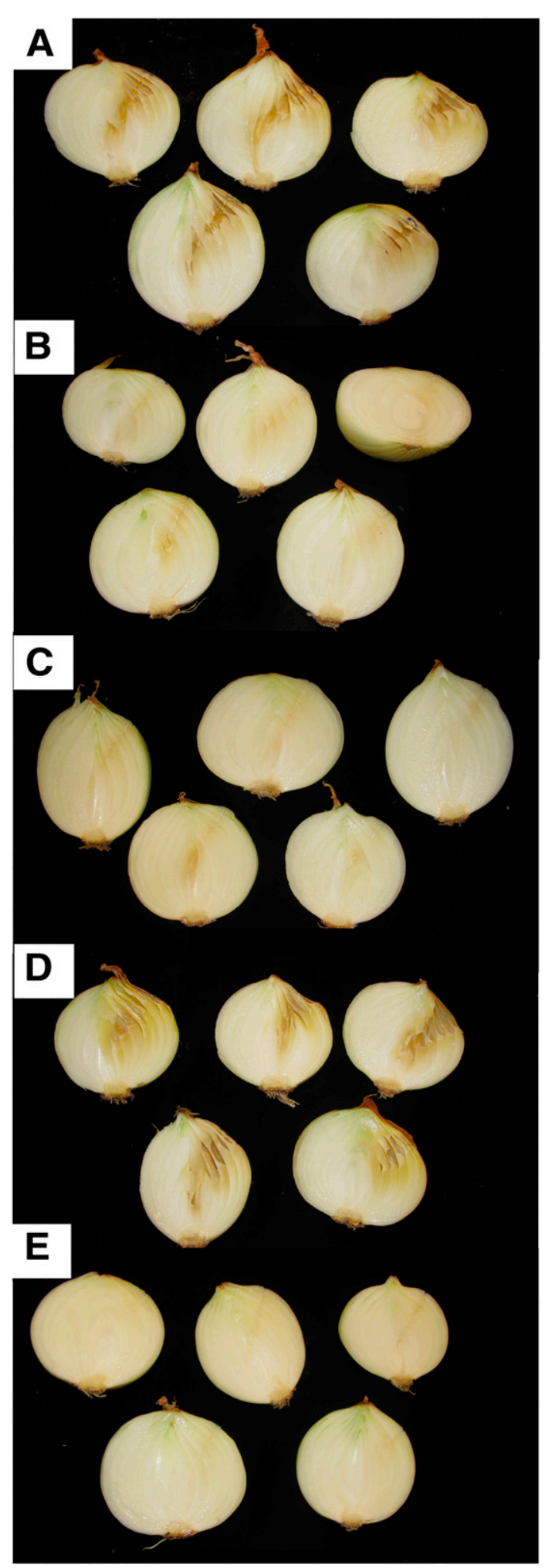

Fig. 3. Onion bulbs 14 days after inoculation with Pantoea ananatis OC5a $\mathrm{Rp}^{\mathrm{r}}$ wild type (WT) and derivatives. A, WT; B, $\Delta$ pepM mutant; C, $\Delta$ pepM complemented in trans; $\mathbf{D}, \Delta p e p M$ empty vector; and $\mathbf{E}$, water. Bulbs were incubated at $28^{\circ} \mathrm{C}$ for 14 days. 
Screening of onion-pathogenic and onion-nonpathogenic strains of $P$. ananatis with primers that amplify a portion of PANA_3283 suggested that there is a strong correlation between the presence of an amplifiable version of this gene and the ability to cause disease in onion leaves. Further, among sequenced $P$. ananatis strains, the HiVir cluster, when present, seems to be whole and highly conserved, suggesting that detection of PANA_3283 by polymerase chain reaction (PCR) would often indicate the presence of a complete HiVir cluster.

The loss of virulence in onion leaves by a $P$. ananatis PANA_3283 deletion mutant further suggested that genes of the HiVir cluster play a role in center rot symptom development. However, deletion of a putative transport protein gene might be partially overcome by nonspecific activity of other $P$. ananatis transporters or, possibly, by bacterial cell lysis. Therefore, the pepM gene, predicted to encode an enzyme critical to the putative biosynthetic function of the HiVir cluster, was next targeted for deletion.

The pepM deletion mutant of $P$. ananatis did not cause lesions in inoculated onion leaves and did not produce watersoaking in yellow storage onion bulbs. Furthermore, bacterial multiplication of pepM mutants in onion leaves, compared with wild-type bacteria, was significantly reduced. Providing copies of pepM in trans complemented the mutant phenotypes. These data demonstrated that the pepM gene of $P$. ananatis confers a growth benefit in onion leaves and is essential for symptom development in onion plants by this center rot pathogen. This is the first gene demonstrated as critical for symptom development in both leaves and bulbs and for bacterial fitness in planta in a center rot disease pathogen.

Previously, Shyntum et al. (2015) demonstrated that T6SS-1 is critical for the development of leaf lesions in center rot of

\section{Symptom severity in onion bulbs}

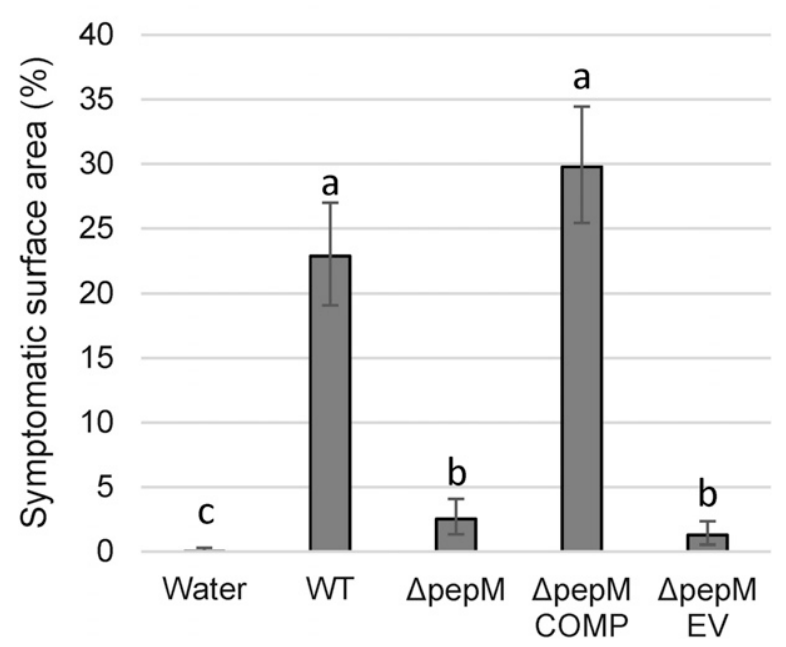

Fig. 4. Symptom severity in bulbs inoculated with Pantoea ananatis strains or water. Bulbs were inoculated with $P$. ananatis $\mathrm{OC5}$ a $\mathrm{Rp}^{\mathrm{r}}$ wild type (WT) and the derivatives $\triangle p e p M$ mutant, $\Delta p e p M$ complemented in trans (COMP), and $\Delta$ pep $M$ empty vector $(\mathrm{EV})$. The percentage of the cut surface area of each bulb was calculated. Symptoms were not entirely distinguishable from wound response, resulting in nonzero values for some water-treated bulbs. Bars represent back-transformed least squares means of the percentage of the bulb surface area that appeared symptomatic. Error bars represent $95 \%$ confidence intervals. A two-way analysis of variance with treatment and inoculation date (corresponding to separate replicates of the experiment) followed by post hoc multiple comparison with a Tukey correction was used to determine statistical differences. Treatments having a different letter are significantly different from each other. onion caused by $P$. ananatis. However, multiplication in onion leaves did not appear to be affected in their experiments. Perhaps bacterial growth is independent of lesion development and a product of the HiVir cluster and type VI effectors might act in concert to cause lesions.

Work by Kido et al. (2010) suggested that $P$. ananatis strains can be grouped into several categories based on host specificity. One of these groups, strains pathogenic to rice and Welsh onion
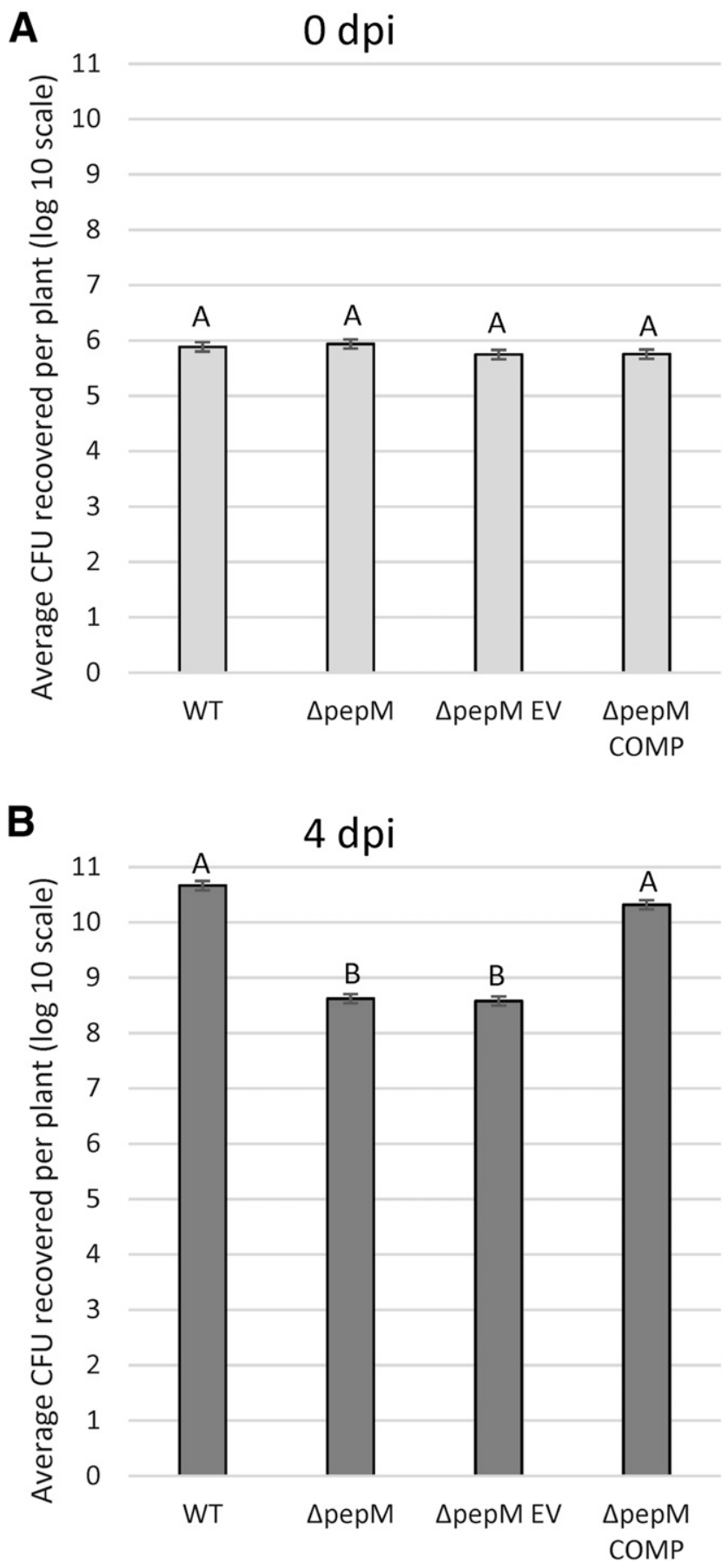

Fig. 5. Bacterial recovery from cultivar Hendrix onion leaves inoculated with Pantoea ananatis strains. Leaves were inoculated with Pantoea ananatis OC5a $\mathrm{Rp}^{\mathrm{r}}$ wild type (WT) and the derivatives $\triangle$ pepM mutant, $\Delta$ pepM complemented in trans (COMP), and $\triangle$ (CepM empty vector (EV). Bacteria were recovered $\mathbf{A}, 0$ or $\mathbf{B}, 4$ days postinoculation (dpi) from two pooled leaves per plant. Error bars represent standard error. Bars with different letters are significantly different within each time period. Comparisons within treatments between time periods were always significantly different. 
(an Allium species distinct from Allium cepa), also had the ability to cause an HR-like cell death in infiltrated tobacco leaf sections. $P$. ananatis strains pathogenic to maize and onion are also reported to cause reactions in tobacco (Alippi and López 2010; Carr et al. 2010). The ability to cause tobacco tissue collapse and cell death in infiltrated leaves, therefore, seems to be common among $P$. ananatis strains with pathogenicity to various Allium species. Deletion of pepM from Pan OC5a $\mathrm{Rp}^{\mathrm{r}}$ also resulted in loss of the ability to cause or elicit cell death in tobacco. The role of the HiVir gene cluster in determining host specificity of $P$. ananatis, if any, is yet to be addressed. Furthermore, studies of the three other bacterial species that cause center rot of onion may indicate whether similar gene clusters play a role in onion-pathogenic strains of those bacteria, as well.

The finding that pep $M$, a gene predicted to be critical to the function of a putative biosynthetic cluster, acts as a pathogenicity determinant opens new avenues for investigating the mechanisms of pathogenesis in center rot-causing bacteria. The individual contributions of other genes of the HiVir cluster remain to be determined, and we currently lack basic knowledge concerning the structure of the product or products of the cluster, their biological targets, transport, and mode of action. We hypothesize that the product is a phosphonate, or possibly a phosphinate, that is toxic to plants. One or more products might be secreted through the major facilitator superfamily protein encoded within the HiVir cluster by PANA_3283. This remains

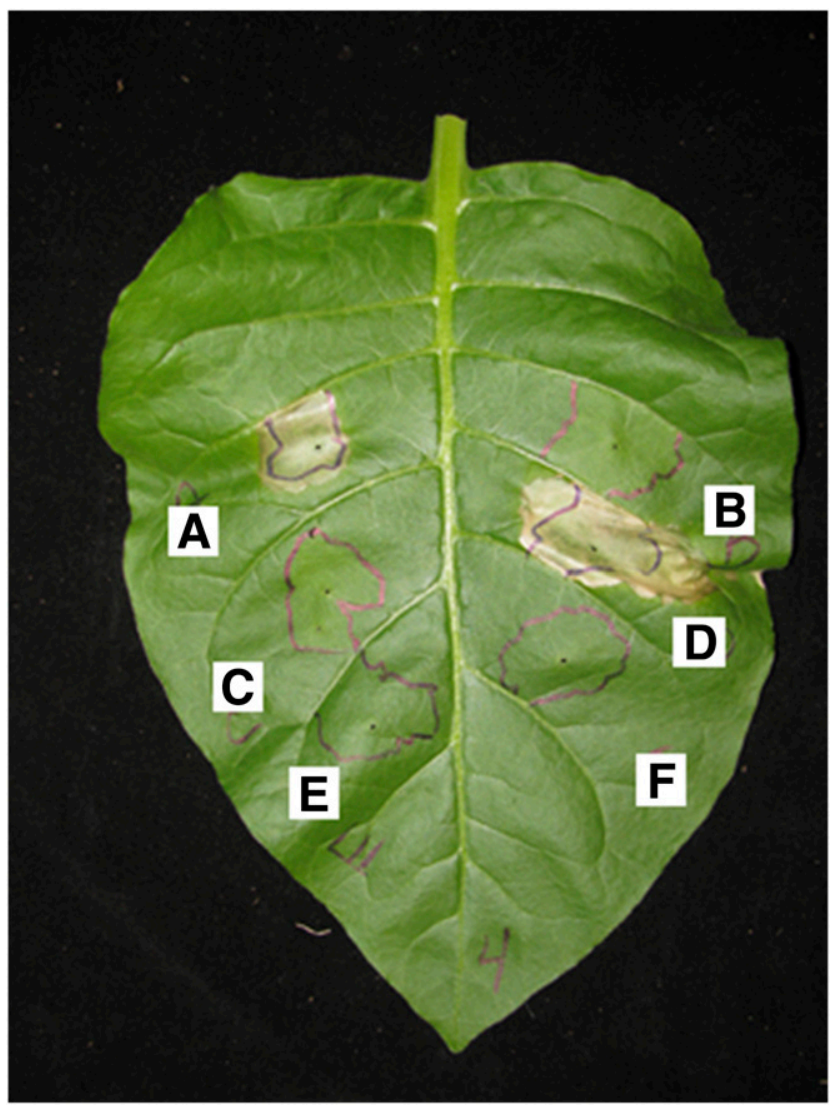

Fig. 6. Collapse and death of portions of tobacco leaf 5 days postinfiltration with A, Pantoea ananatis OC5a Rp ${ }^{\mathrm{r}}$ wild type (WT); B, АpepM; C, $\Delta$ рерM harboring empty vector; $\mathbf{D}, \triangle p e p M$ harboring a complementation construct; E, modified coplin lab medium (mCLM); F, mCLM + kanamycin (the medium used to incubate strains with empty vector or complementation construct). Symptoms became visible 24 to $48 \mathrm{~h}$ after infiltration and continued to develop and spread outside the infiltrated area for several days. to be tested. Biochemical characterization of HiVir products will be critical to address these unknowns.

\section{MATERIALS AND METHODS}

\section{Identification of HiVir region.}

Onion leaves were inoculated with four strains of $P$. ananatis for which genome sequences were available; the pathogenicity of each strain was assessed. Genome sequences for strains LMG 20103 (CP001875.2), LMG 2665 (JMJJ01000001.1 to JMJJ01000017.1), BD442 (JMJL01000001.1 to JMJL01000011.1), and PA4 (JMJK01000001.1 to JMJK01000017.1) were downloaded from NCBI. For whole-genome shotgun sequences, contig sequences for each strain were copied into single text files in fastA format. Sequences from the four strains were aligned using the whole-genome alignment viewer Mauve 2.3.1 (Darling et al. 2010). Genome similarity was assessed visually by scrolling through the alignment and making note of any regions of DNA that appeared to be well-conserved between LMG 20103 and LMG 2665 but were different or missing in strains BD442 and PA4. A list of more than 150 genes was generated from the initial screen. Predicted amino acid sequences for each of the 150 genes, as called in the annotation of LMG 20103, an onion-pathogenic strain, were then compared via BLAST (tblastn) against onion-pathogenic LMG 2665 and onionnonpathogenic BD442 genome sequences. Only protein sequences that were well-conserved in LMG 2665 and more poorly conserved or absent in BD442 were retained, leaving 37 genes. Predicted protein sequences from these 37 genes were then compared with translated genome sequence from strain PA4, resulting in a list of 35 genes. Primers designed to amplify a subset of the 35 genes were screened against nine strains of $P$. ananatis, five pathogenic and four nonpathogenic to onion. One primer pair, designed to anneal within PANA_3283, a gene encoding a putative major facilitator family protein according to the annotation of LMG 20103, produced an amplicon of the expected size only from the five pathogenic strains. PANA_3283 was among the genes assessed in the PCR screen, due to its annotation as a major facilitator superfamily protein. This suggested that it might be involved in transporting small bacterial molecules into the host plant environment. Additionally, PANA_3283 was part of a cluster of genes, PANA_3280 through PANA3292, that were all on the list of 35 genes that had been judged as candidate pathogenicity factors.

Following the result that onion-pathogenic strains of $P$. ananatis produced amplicons from PANA_3283 consistently, the context of the region containing PANA_3283 was examined more closely in strain LMG 20103. Annotated DNA sequence was visualized in SeqBuilder (DNAStar, Madison, WI, U.S.A.), and GC content was assessed for the whole genome and for the DNA in the immediate vicinity of the $18.1-\mathrm{kb}$ region that was conserved between strains LMG 20103 and LMG 2665 in the four-genome Mauve alignment. Genomic island predictions were made using Alien_Hunter and IslandViewer 4 tools (Bertelli et al. 2017; Vernikos and Parkhill 2006). Additional examples of HiVir clusters present in $P$. ananatis strains were found in the NCBI databases, using the BLAST tool, searching for somewhat similar sequences against the nucleotide (nr/nt) and whole-genome shotgun contigs (WGS) databases, limiting search results to genus Pantoea (taxid:53335) for the WGS search. Derived amino acid sequences for predicted HiVir genes were also compared with predicted amino acid sequences from the nr/nt and translated bacterial sequences within WGS databases, to determine whether clusters with functional similarity to HiVir might be present in other sequenced organisms.

\section{Bacterial growth conditions.}

Strains of $P$. ananatis were routinely streaked onto Luria Bertani (LB) agar supplemented with antibiotics, as appropriate, 
and were incubated for 1 to 2 days at $28^{\circ} \mathrm{C}$. Strains of Escherichia coli were routinely grown overnight on $\mathrm{LB}$ agar at $37^{\circ} \mathrm{C}$. For storage, freshly grown bacteria from plates were suspended in $15 \%$ aqueous glycerol and were frozen at $-80^{\circ} \mathrm{C}$.

\section{Preliminary experiment with a PANA_3283 mutant.}

Creation of a PANA_3283 deletion mutant and a complementation construct were performed largely as described for the pepM deletion mutant, as follows. Descriptions of primers used for plasmid construction and additional plasmids and strains are contained in Supplementary Table S1.

Plants were placed in a $30^{\circ} \mathrm{C}$ incubator with $13.5 \mathrm{~h}$ of light per day, 1 day prior to inoculation. Inoculations were performed using bacterial suspensions in water set to an optical density at $600 \mathrm{~nm}\left(\mathrm{OD}_{600}\right)$ of 0.2 . For each strain, five leaves were inoculated per plant, and three plants were inoculated per strain. The experiment was carried out twice. Immediately following inoculation, plants were returned to the incubator and remained there over the course of the experiment, except when they were being measured. Lesion lengths were measured for each inoculation at 2, 4, and 6 dpi.

Leaves mock-inoculated with water never developed lesions and were removed from the analysis. Lesion-length data were transformed by adding 0.1 to each data point and taking the natural log. A mixed model was used because, from each plant, lesions were measured over five leaves, and lesions from inoculated leaves were repeatedly measured over time. The dependent variable was lesion length. Fixed independent variables were strain used, inoculation date, days postinoculation, and the interaction between strain and days postinoculation. Random effects were plants nested within strain and leaves nested within plants, within strains. The analysis was followed by multiple comparisons using a Tukey correction. Statistical analysis was performed using JMP 13 (SAS Institute, Inc., Cary, NC, U.S.A.)

\section{Production of pepM clones and mutants.}

The pepM deletion construct pCPP1840 contained DNA immediately upstream and downstream of the pepM gene and also the first two and last 26 codons of the open reading frame, in an effort to prevent polar effects. Upstream DNA was cloned using the primer pair OprnDltn LE F SalI (5'-CGC GGT CGA CAC TAT GAA TGT GTG CTG CGA AGA-3') and pepM LE R EcoRI (5'-CGC GGA ATT CGA TCA TAT AAA CAC CTT TGA TGC GT- $3^{\prime}$ ) with the following reaction conditions: $12 \mu \mathrm{l}$ of total volume, $5.09 \mu \mathrm{l}$ of sterile-filtered high-purity (HP) water, $2.4 \mu \mathrm{l}$ of OneTaq High GC buffer, $1.2 \mu \mathrm{l}$ of $2.5 \mathrm{mM}$ dNTPs, $0.625 \mu \mathrm{l}$ of each primer at $10 \mu \mathrm{M}, 0.06 \mu \mathrm{l}$ of OneTaq, and $2 \mu \mathrm{l}$ of Pan OC5a genomic DNA at $1 \mathrm{ng} / \mu \mathrm{l}$. Cycling conditions were as follows: $95^{\circ} \mathrm{C}$ for $10 \mathrm{~min}, 35$ cycles of $95^{\circ} \mathrm{C}$ for $30 \mathrm{~s}, 55.7^{\circ} \mathrm{C}$ for $45 \mathrm{~s}, 68^{\circ} \mathrm{C}$ for $1 \mathrm{~min} 25 \mathrm{~s}$, followed by a final extension of $68^{\circ} \mathrm{C}$ for $10 \mathrm{~min}, 12^{\circ} \mathrm{C}$ hold. DNA downstream of pep $M$ were cloned using pepM RE R SpeI (5'-CGC GAC TAG TCT GGT AAT GGT CCT TCA GGA TC-3') and pepM RE F EcoRI (5'-CGC GGA ATT CAT ATT GAG ATA TGG CAG GAC GGC AGA-3') with the following reaction conditions: $25 \mu \mathrm{l}$ of total volume, $17 \mu \mathrm{l}$ of water, $2.5 \mu \mathrm{l}$ of $10 \times$ reaction buffer, $2 \mu \mathrm{l}$ of $2.5 \mathrm{mM}$ dNTPs, $0.5 \mu \mathrm{l}$ of template DNA (Pan OC5a genomic DNA at $119 \mathrm{ng} / \mu \mathrm{l}), 1.25 \mu \mathrm{l}$ of each primer at $10 \mu \mathrm{M}, 0.5 \mu \mathrm{l}$ of PfuTurbo DNA polymerase. Upstream DNA was digested using restriction endonucleases SalI and EcoRI, and downstream DNA was digested using EcoRI and SpeI (New England Biolabs, Ipswich, MaMA, U.S.A.). DNA was cleaned using the DNA Clean \& Concentrator-5 kit (Zymo Research, Irvine, CA, U.S.A.) following both amplification and digestion. Inserts were ligated into pBC SK- (Table 2) digested with SalI and SpeI. After confirmation of successful cloning, the insert was excised by digesting the resulting plasmid with SalI and SpeI and was separated from the vector backbone by gel purification and clean-up using the Zymoclean gel DNA recovery kit (Zymo Research). The insert was ligated into pKNG101, cut with the same enzymes, and transformed via electroporation into $E$. coli $\mathrm{Sm} 10 \lambda$ pir. The pepM mutant was created by mating

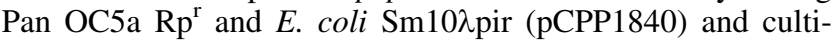
vating and selecting for first and second crossover mutants as described by Bogdanove et al. (1996). Putative second crossover mutants were screened by PCR, using primers that anneal upstream and downstream of the DNA targeted for homologous recombination by pCPP1840. Amplicons of different sizes were produced from deletion mutants and revertants. Amplicons from putative deletion mutants were sequenced at the Biotechnology Resource Center (BRC) at Cornell University for confirmation that the gene was deleted.

The pepM complementation construct pCPP1838 contains the pepM gene and $22 \mathrm{bp}$ of upstream DNA cloned into pML122 at XhoI and BamHI sites. The insert was created by PCR with the pepM-F XhoI (5'-CCG GCT CGA GTT TAC GCA TCA AAG GTG TTT ATA TG-3') and pepM-R BamHI (5'-CGC GGG ATC CCT TTA AGG AAT CAG TGA AAT AA$\left.3^{\prime}\right)$ primer pair under the following conditions: $12.5 \mu \mathrm{l}$ of total

Table 2. Plasmids and strains used in creating and characterizing pepM mutants in an onion-pathogenic strain of Pantoea ananatis

\begin{tabular}{|c|c|c|}
\hline Name & Description $^{a}$ & Reference \\
\hline pBC SK- & High copy number phagemid; ColE1 origin; $\mathrm{Cm}^{\mathrm{r}}$ & Stratagene, La Jolla, CA, U.S.A. \\
\hline pCPP1840 & $\begin{array}{l}1,250 \text { bp upstream of pep } M \text { and the first two codons of pepM and the last } 26 \\
\text { codons of pepM and } 984 \text { bp downstream of pep } M \text { were cloned into pKNG101; } \\
\mathrm{Sm}^{\mathrm{r}}\end{array}$ & This study \\
\hline pCPP1838 & $\begin{array}{l}\text { pepM gene }+22 \text { bp upstream from Pantoea ananatis OC5a cloned into pML122 at } \\
\text { XhoI and BamHI sites; } \mathrm{Gm}^{\mathrm{r}}, \mathrm{Km}^{\mathrm{r}}\end{array}$ & This study \\
\hline pML122 & $\begin{array}{l}\text { Empty expression vector, includes pNm promoter to drive expression of cloned } \\
\text { genes; } \mathrm{Gm}^{\mathrm{r}}, \mathrm{Km}^{\mathrm{r}}\end{array}$ & Labes et al. 1990 \\
\hline pKNG101 & Suicide vector used for creating deletion mutants in $P$. ananatis; $\mathrm{Sm}^{\mathrm{r}}$ & Kaniga et al. 1991 \\
\hline \multicolumn{3}{|l|}{ P. ananatis strains } \\
\hline OC5a Rp ${ }^{r}$ wild type (WT) & A spontaneous Rp-resistant mutant of $P$. ananatis $\mathrm{OC} 5 \mathrm{a} ; \mathrm{Rp}^{\mathrm{r}}$ & This study \\
\hline OC5a Rp ${ }^{\mathrm{r}} \Delta p e p M$ & A pep $M$ deletion mutant of OC5a Rp ${ }^{\mathrm{r}} \mathrm{WT} ; \mathrm{Rp}^{\mathrm{r}}$ & This study \\
\hline OC5a Rp ${ }^{\mathrm{r}} \Delta p e p M(\mathrm{pCPP} 1838)$ & $\begin{array}{l}\text { OC5a Rp }{ }^{r} \Delta p e p M \text { harboring the pepM complementation construct pCPP1838; } \mathrm{Rp}^{\mathrm{r}} \text {, } \\
\mathrm{Gm}^{\mathrm{r}}, \mathrm{Km}^{\mathrm{r}}\end{array}$ & This study \\
\hline OC5a $\mathrm{Rp}^{\mathrm{r}}$ АpepM(pML122) & OC5a $\mathrm{Rp}^{r}$ ApepM harboring the empty vector $\mathrm{pML} 122 ; \mathrm{Rp}^{\mathrm{r}}, \mathrm{Km}^{\mathrm{r}}, \mathrm{Gm}^{\mathrm{r}}$ & This study \\
\hline \multicolumn{3}{|l|}{ Escherichia coli strains } \\
\hline DH5 $\alpha$ & 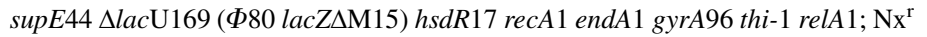 & Sambrook et al. 1989 \\
\hline Sm10 1 pir & thi thr leu tonA lacY supE recA::RP4-2-Tc::Mu Km $\lambda$ pir; $\mathrm{Km}^{\mathrm{r}}$ & Miller and Mekalanos 1988 \\
\hline
\end{tabular}

\footnotetext{
${ }^{\mathrm{a}} \mathrm{Cm}^{\mathrm{r}}, \mathrm{Gm}^{\mathrm{r}}, \mathrm{Km}^{\mathrm{r}}, \mathrm{Nx}^{\mathrm{r}}, \mathrm{Rp}^{\mathrm{r}}$, and $\mathrm{Sm}^{\mathrm{r}}$ = resistance to chloramphenicol, gentamycin, kanamycin, nalidixic acid, rifampicin, and streptomycin, respectively.
} 
reaction volume, $5.5 \mu \mathrm{l}$ of water, $2.5 \mu \mathrm{l}$ of $5 \times \mathrm{Q} 5$ reaction buffer, $1 \mu \mathrm{l}$ of $2.5 \mathrm{mM}$ dNTPs, $0.625 \mu \mathrm{l}$ of each primer at $10 \mu \mathrm{M}$, $0.25 \mu \mathrm{l}$ of Q5 high fidelity polymerase (New England Biolabs) and $2 \mu \mathrm{l}$ of Pan OC5a genomic DNA at $2.5 \mathrm{ng} / \mu \mathrm{l}$. Cycling conditions were $98^{\circ} \mathrm{C}$ for $30 \mathrm{~s}, 35$ cycles of $98^{\circ} \mathrm{C}$ for $10 \mathrm{~s}, 56^{\circ} \mathrm{C}$ for $30 \mathrm{~s}, 72^{\circ} \mathrm{C}$ for $30 \mathrm{~s}$, followed by a final extension of $72^{\circ} \mathrm{C}$ for $2 \mathrm{~min}, 10^{\circ} \mathrm{C}$ hold. DNA was cleaned, and both insert and vector were digested with BamHI and XhoI (New England Biolabs). DNA was cleaned following both amplification and digestion, as previously described. DNA insert and vector were ligated using T4 DNA ligase (New England Biolabs) and were transformed into E. coli DH5 $\alpha$ cells via electroporation. Plasmids were isolated using the GeneJet plasmid miniprep kit (ThermoFisher Scientific, Waltham, MA, U.S.A.) and were sequenced at the BRC to confirm that the cloned sequences were correct. Plasmid pCPP1838 (complementation construct) and pML122 (empty vector) were introduced into Pan OC5a Rp ${ }^{\mathrm{r}}$ WT and $\triangle p e p M$ strains via electroporation.

\section{Preparation of inocula for onion leaves and bulbs.}

To introduce bacteria into onion tissue, inocula were prepared from bacteria growing on LB agar plates, supplemented with appropriate antibiotics, that had been incubated overnight at $28^{\circ} \mathrm{C}$. Sterile cotton-tipped applicators were used to collect bacteria, which were transferred to autoclaved HP water to $\mathrm{OD}_{600}=0.2$.

\section{Screening of strains for onion pathogenicity and with PANA_3283 PCR primers.}

Thirty strains of $P$. ananatis were screened with primers PANA_3283 64-85F (5'-GCT GAA GGG ATT CAG ACG GTT A-3') and PANA_3283 812-833R (5'-GCT GCT ATC CCC GAG ATA ATG A-3'). Reactions were made to $12 \mu \mathrm{l}$ of total volume, $5.09 \mu \mathrm{l}$ of sterile-filtered HP water, $2.4 \mu \mathrm{l}$ of OneTaq Standard buffer, $1.2 \mu \mathrm{l}$ of $2.5 \mathrm{mM}$ dNTPs, $0.625 \mu \mathrm{l}$ of each primer at $10 \mu \mathrm{M}, 0.06 \mu$ l of OneTaq DNA polymerase (New England Biolabs), and $2 \mu \mathrm{l}$ of template. Bacterial suspensions were used as templates for PCR. Sterile wooden applicators were lightly touched to 1- to 2-day-old plate cultures seven to 10 times and the applicators then were swished in $200 \mu \mathrm{l}$ of water to generate bacterial suspensions. Cycling conditions were $95^{\circ} \mathrm{C}$ for $10 \mathrm{~min}, 45$ cycles of $94^{\circ} \mathrm{C}$ for $30 \mathrm{~s}$, $54^{\circ} \mathrm{C}$ for $45 \mathrm{~s}, 72^{\circ} \mathrm{C}$ for 45 to $50 \mathrm{~s}$, followed by a final extension of $72^{\circ} \mathrm{C}$ for 10 min with a $12^{\circ} \mathrm{C}$ hold. Amplicons were visualized via gel electrophoresis. An initial experiment, using a subset of nine strains, involved screening for pathogenicity in yellow storage onion bulbs, as described for other bulb assays, except strains were screened in two bulbs each and were incubated at $37^{\circ} \mathrm{C}$ for 7 days. Subsequently, all 30 strains listed in Table 1 were screened for pathogenicity in onion leaves from cv. Prince 12 weeks after sowing. Strains were inoculated into two leaves each on two separate plants. Plants were incubated at $30^{\circ} \mathrm{C}$ with $13.5 \mathrm{~h}$ of light. Leaves were observed for lesions $3 \mathrm{dpi}$ and were rated for the presence or absence of lesions. Strains were considered positive for pathogenicity if at least three of four leaves had developed lesions. Strains were considered negative for pathogenicity if no inoculated leaves had lesions.

\section{Onion leaf lesion assays with pepM mutant bacteria.}

Yellow storage onion plants from cv. Hendrix were grown as described by Bonasera et al. (2017). Onion leaves from plants grown from 13 to 19 weeks were inoculated by dipping sterile toothpicks in inocula (bacterial suspensions adjusted to an $\mathrm{OD}_{600}=0.2$ ) and stabbing leaves approximately $10 \mathrm{~cm}$ above the soil line. Pan OC5a Rp ${ }^{\mathrm{r}} \mathrm{WT}, \Delta p e p M, \Delta p e p M$ EV (Labes et al. 1990), and $\triangle$ leaves; water was mock-inoculated as a negative control. The five youngest leaves of sufficient height were inoculated per plant inoculated. Plants were placed in an illuminated incubator set to $30^{\circ} \mathrm{C}$. Lesion length was measured 2, 3, 4, and 5 dpi.

Lesions were assigned binary values: 0 for no lesion and 1 for lesion. Some lesion data were missing for leaves at $5 \mathrm{dpi}$, as leaf senescence for some older leaves made measuring lesions impossible. Statistical analysis was done separately per day postinoculation, using a contingency table between binary lesion value and treatment. Because of rare events (lack of lesion), data were combined among the three replications and two-tailed Fisher's exact test was used with a value of less than 0.05 deemed significant. The analysis was run using JMP 13 (SAS Institute, Inc.). Treatments that did not produce lesions were removed from the analysis.

\section{Bulb assays with pepM mutant bacteria.}

Yellow onion bulbs were purchased from a local grocery store and were peeled to remove the outermost papery scales. Outer fleshy scales were also removed if they were brown instead of yellow past the bulb shoulder or if they had blemishes that could indicate early stages of fungal infection. Bulbs were then submerged in $10 \%$ household bleach for $2 \mathrm{~min}$, were rinsed in HP water, were rinsed in $95 \%$ ethanol, and were allowed to dry. Inocula were prepared as described for leaf assays. Toothpicks dipped in inocula were stabbed into bulb shoulders to a depth of approximately 4 to $4.5 \mathrm{~cm}$.

For experiments to test the role of the pep $M$ gene in disease, onion bulbs were stabbed with toothpicks that had been dipped in suspensions of Pan OC5a $\mathrm{Rp}^{\mathrm{r}}$ WT, $\triangle$ pepM COMP, and water. After inoculation, bulbs were placed in plastic bags and were incubated at $28^{\circ} \mathrm{C}$ for 14 days. Five bulbs were inoculated per treatment, and the experiment was performed three separate times. At the end of the incubation period, bulbs were cut open longitudinally through their inoculation sites and were photographed. Photographs of one half of the cut surface of each bulb were analyzed using Photoshop CC 19.0 (Adobe Systems Incorporated, San Jose, CA, U.S.A.). The total surface areas of the cut bulb face, sans basal plate, and the symptomatic surface area were measured. Tissues were considered symptomatic if they appeared discolored, had shrunken scales, or were water-soaked. The percentage of the total cut surface area that was symptomatic was then calculated. Bulbs with symptoms not characteristic of $P$. ananatis infection, including severe maceration or with symptoms that appeared to have originated in the neck of the bulb instead of at the inoculation site were assumed to have been contaminated with other pathogenic bacteria or fungi and were removed from further analysis. A total of four bulbs from three different treatments were removed for this reason.

A general linear model (two-way analysis of variance) was carried out to assess the association between percent symptomatic area and treatment, controlling for inoculation date. To fit the assumption of the general linear model, a square root transformation was applied to the responses. The general linear model analysis was followed by a post hoc multiple comparison with a Tukey correction. Responses were considered significantly different with $P$ values of less than 0.05 . The analysis was run using JMP 13 (SAS Institute, Inc.).

\section{Recovery of bacteria from onion leaves.}

Plants were used 12 to 15 weeks after sowing. Because onions were grown in a controlled environment chamber with changing conditions over the course of growth, onions used were sown at one time, and, with each replication of the experiment, plants were 1 week older than in the previous experiment. Plants were placed in an incubator set to $30^{\circ} \mathrm{C}$ with 
$13.5 \mathrm{~h}$ of light per day, 1 day prior to inoculation. After inoculation of plants and immediately following bacterial recovery at $0 \mathrm{dpi}$, plants were returned to the incubator until leaves were harvested at $4 \mathrm{dpi}$. Onion leaves were inoculated as for leaf lesion assays with Pan OC5a Rp ${ }^{\mathrm{r}} \mathrm{WT}, \Delta p e p M$, $\Delta$ рерM EV, $\Delta$ рерM COMP, or water. At 0 and $4 \mathrm{dpi}$, the second and fourth youngest inoculated leaves were harvested, were placed in a disinfested blender cup with $100 \mathrm{ml}$ of autoclaved HP water, and were blended thoroughly. Serial 10fold dilutions of the resulting blendates were prepared in HP water. Five-microliter spots of blendates and dilutions thereof were spotted onto LB agar supplemented with rifampicin. Colony-forming units (CFU) per $100 \mathrm{ml}$ of blendates were calculated from the average of four or five spots. For each timepoint, leaves from three plants were ground per treatment (bacterial strain or water), and the experiment was carried out four times.

A general linear model was used to analyze the data. The dependent variable was the $\log _{10}$ of the bacteria recovered per plant (two leaves were harvested per plant and pooled), and the independent variables were treatment (strain used), inoculation date, days postinoculation (whether leaves were harvested at 0 or 4 days after inoculation), and the interaction between treatment and days postinoculation. The analysis was followed by posthoc comparisons between treatment levels within each days-postinoculation level and between days postinoculation for each treatment level. A Bonferonni correction for multiple comparisons was applied. In total, 16 comparisons were made: six comparisons among treatments at $0 \mathrm{dpi}$, six comparisons among treatments at $4 \mathrm{dpi}$, and four comparisons between the same treatment at 0 and $4 \mathrm{dpi}$.

\section{Tobacco infiltrations.}

$P$. ananatis strains for use in tobacco infiltrations were grown in modified Coplin lab medium (mCLM) $\left[1 \mathrm{mM}\left(\mathrm{NH}_{4}\right)_{2} \mathrm{SO}_{4}\right.$, $0.5 \mathrm{mM} \mathrm{KH} \mathrm{PO}_{4}, 0.5 \mathrm{mM} \mathrm{MgSO}$, $50 \mathrm{mM} \mathrm{MES,} 0.05 \%$ casamino acids, $2 \%$ sucrose, brought to $\mathrm{pH}=5.50$ with $1 \mathrm{M}$ $\mathrm{NaOH}$ and filter sterilized] (Nizan et al. 1997). Preliminary work suggested that growth of $P$. ananatis in LB broth followed by resuspension in water gave less-reliable results for WT bacteria than growing and infiltrating cultures in MCLM. Other researchers have also reported that resuspension of $P$. ananatis in water led to negative reactions compared with use of other media in tobacco (Kido et al. 2010). Cultures were grown overnight in $\mathrm{mCLM}$ at $28^{\circ} \mathrm{C}$ with shaking at $200 \mathrm{rpm}$. The following day, the cultures were normalized using MCLM to the $\mathrm{OD}_{600}$ of the culture that had grown the least (approximate $\mathrm{OD}_{600}=0.4$ for a $1: 5$ dilution of the cultures). Normalized cultures were infiltrated into tobacco leaf panels using needleless syringes. Infiltrated areas were immediately outlined with a black marker. Plants were observed over 5 days for signs of tissue collapse and cell death. The assay was performed on two or three leaves from each of three plants. The experiment was conducted three times.

\section{ACKNOWLEDGMENTS}

We thank F. Vermeylen of the Cornell Statistical Consulting Unit for statistical analyses of the data. We thank R. Gitaitis and Y. Takikawa for their kind gifts of strains. We thank D. Schneider for bioinformatics help using Alien_Hunter.

\section{LITERATURE CITED}

Adam, Z., Tambong, J. T., Lewis, C. T., Lévesque, C. A., Chen, W., Bromfield, E. S. P., Khan, I. U. H., and Xu, R. 2014. Draft genome sequence of Pantoea ananatis strain LMG $2665^{\mathrm{T}}$, a bacterial pathogen of pineapple fruitlets. Genome Announc. 2:e00489-14.
Adeolu, M., Alnajar, S., Naushad, S., and Gupta, R. S. 2016. Genome-based phylogeny and taxonomy of the 'Enterobacteriales': Proposal for Enterobacterales ord. nov. divided into the families Enterobacteriaceae, Erwiniaceae fam. nov., Pectobacteriaceae fam. nov., Yersiniaceae fam. nov., Hafniaceae fam. nov., Morganellaceae fam. nov., and Budviciaceae fam. nov. Int. J. Syst. Evol. Microbiol. 66:5575-5599.

Alippi, A. M., and López, A. C. 2010. First report of leaf spot disease of maize caused by Pantoea ananatis in Argentina. Plant Dis. 94:487.

Asselin, J. E., Bonasera, J. M., and Beer, S. V. 2016. PCR primers for detection of Pantoea ananatis, Burkholderia spp., and Enterobacter sp. from onion. Plant Dis. 100:836-846.

Bertelli, C., Laird, M. R., Williams, K. P., Simon Fraser University Research Computing Group, Lau, B. Y., Hoad, G., Winsor, G. L., and Brinkman, F. S. L. 2017. IslandViewer 4: Expanded prediction of genomic islands for larger-scale datasets. Nucleic Acids Res. 45 (W1): W30-W35.

Bogdanove, A. J., Wei, Z.-M., Zhao, L., and Beer, S. V. 1996. Erwinia amylovora secretes harpin via a type III pathway and contains a homolog of yopN of Yersinia spp. J. Bacteriol. 178:1720-1730.

Bonasera, J. M., Asselin, J. E., and Beer, S. V. 2014. Identification of bacteria pathogenic to or associated with onion (Allium cepa) based on sequence differences in a portion of the conserved gyrase B gene. J. Microbiol. Methods 103:138-143.

Bonasera, J. M., Asselin, J. E., and Beer, S. V. 2017. Lactic acid bacteria cause a leaf blight and bulb decay of onion (Allium cepa). Plant Dis. 101: 29-33.

Borisova, S. A., Circello, B. T., Zhang, J. K., van der Donk, W. A., and Metcalf, W. W. 2010. Biosynthesis of rhizocticins, antifungal phosphonate oligopeptides produced by Bacillus subtilis ATCC6633. Chem. Biol. 17:28-37.

Brady, C., Cleenwerck, I., Venter, S., Vancanneyt, M., Swings, J., and Coutinho, T. 2008. Phylogeny and identification of Pantoea species associated with plants, humans and the natural environment based on multilocus sequence analysis (MLSA). Syst. Appl. Microbiol. 31: 447-460.

Brady, C. L., Goszczynska, T., Venter, S. N., Cleenwerck, I., De Vos, P., Gitaitis, R. D., and Coutinho, T. A. 2011. Pantoea allii sp. nov., isolated from onion plants and seed. Int. J. Syst. Evol. Microbiol. 61:932-937.

Carr, E. A., Bonasera, J. M., Zaid, A. M., Lorbeer, J. W., and Beer, S. V. 2010. First report of bulb disease of onion caused by Pantoea ananatis in New York. Plant Dis. 94:916.

Carr, E. A., Zaid, A. M., Bonasera, J. M., Lorbeer, J. W., and Beer, S. V. 2013. Infection of onion leaves by Pantoea ananatis leads to bulb infection. Plant Dis. 97:1524-1528.

Darling, A. E., Mau, B., and Perna, N. T. 2010. progressiveMauve: Multiple genome alignment with gene gain, loss and rearrangement. PLoS One 5: e11147.

De Maayer, P., Chan, W. Y., Rubagotti, E., Venter, S. N., Toth, I. K., Birch, P. R., and Coutinho, T. A. 2014. Analysis of the Pantoea ananatis pangenome reveals factors underlying its ability to colonize and interact with plant, insect and vertebrate hosts. BMC Genomics 15:404.

De Maayer, P., Chan, W. Y., Venter, S. N., Toth, I. K., Birch, P. R. J., Joubert, F., and Coutinho, T. A. 2010. Genome sequence of Pantoea ananatis LMG20103, the causative agent of Eucalyptus blight and dieback. J. Bacteriol. 192:2936-2937.

Dutta, B., Barman, A. K., Srinivasan, R., Avci, U., Ullman, D. E., Langston, D. B., and Gitaitis, R. D. 2014. Transmission of Pantoea ananatis and P. agglomerans, causal agents of center rot of onion (Allium cepa), by onion thrips (Thrips tabaci) through feces. Phytopathology 104:812-819.

Dutta, B., Gitaitis, R., Barman, A., Avci, U., Marasigan, K., and Srinivasan, R. 2016. Interactions between Frankliniella fusca and Pantoea ananatis in the center rot epidemic of onion (Allium cepa). Phytopathology 106: 956-962.

Eliot, A. C., Griffin, B. M., Thomas, P. M., Johannes, T. W., Kelleher, N. L., Zhao, H., and Metcalf, W. W. 2008. Cloning, expression, and biochemical characterization of Streptomyces rubellomurinus genes required for biosynthesis of antimalarial compound FR900098. Chem. Biol. 15:765-770.

Frederick, R. D., Ahmad, M., Majerczak, D. R., Arroyo-Rodríguez, A. S., Manulis, S., and Coplin, D. L. 2001. Genetic organization of the Pantoea stewartii subsp. stewartii hrp gene cluster and sequence analysis of the $h r p A, h r p C, h r p N$, and $w t s E$ operons. Mol. Plant-Microbe Interact 14: 1213-1222.

Gitaitis, R. D., and Gay, J. D. 1997. First report of a leaf blight, seed stalk rot, and bulb decay on onion by Pantoea ananas in Georgia. Plant Dis. $81: 1096$.

Hattingh, M. J., and Walters, D. F. 1981. Stalk and leaf necrosis of onion caused by Erwinia herbicola. Plant Dis. 65:615-618. 
Horsman, G. P., and Zechel, D. L. 2017. Phosphonate biochemistry. Chem. Rev. 117:5704-5783.

Kaniga, K., Delor, I., and Cornelis, G. R. 1991. A wide-host-range suicide vector for improving reverse genetics in gram-negative bacteria: Inactivation of the blaA gene of Yersinia enterocolitica. Gene 109: 137-141.

Kido, K., Hasegawa, M., Matsumoto, H., Kobayashi, M., and Takikawa, Y. 2010. Pantoea ananatis strains are differentiated into three groups based on reactions of tobacco and welsh onion and on genetic characteristics. J. Gen. Plant Pathol. 76:208-218.

Kim, J., Choi, O., and Kim, T.-S. 2012. An outbreak of onion center rot caused by Pantoea ananatis in Korea. Plant Dis. 96:1576.

Labes, M., Pühler, A., and Simon, R. 1990. A new family of RSF1010derived expression and lac-fusion broad-host-range vectors for gramnegative bacteria. Gene 89:37-46.

Metcalf, W. W., and van der Donk, W. A. 2009. Biosynthesis of phosphonic and phosphinic acid natural products. Annu. Rev. Biochem. 78:65-94.

Miller, V. L., and Mekalanos, J. J. 1988. A novel suicide vector and its use in construction of insertion mutations: Osmoregulation of outer membrane proteins and virulence determinants in Vibrio cholerae requires toxR. J. Bacteriol. 170:2575-2583.

Morohoshi, T., Nakamura, Y., Yamazaki, G., Ishida, A., Kato, N., and Ikeda, T. 2007. The plant pathogen Pantoea ananatis produces Nacylhomoserine lactone and causes center rot disease of onion by quorum sensing. J. Bacteriol. 189:8333-8338.

Nakashita, H., Watanabe, K., Hara, O., Hidaka, T., and Seto, H. 1997. Studies on the biosynthesis of bialaphos. Biochemical mechanism of C-P bond formation: Discovery of phosphonopyruvate decarboxylase which catalyzes the formation of phosphonoacetaldehyde from phosphonopyruvate. J. Antibiot. (Tokyo) 50:212-219.

Nizan, R., Barash, I., Valinsky, L., Lichter, A., and Manulis, S. 1997. The presence of hrp genes on the pathogenicity-associated plasmid of the tumorigenic bacterium Erwinia herbicola pv. gypsophilae. Mol. PlantMicrobe Interact 10:677-682.

Peck, S. C., Gao, J., and van der Donk, W. A. 2012. Discovery and biosynthesis of phosphonate and phosphinate natural products. Methods Enzymol. 516:101-123.

Sambrook, J. Fritsch, E. F., and Maniatis, T. 1989. Molecular Cloning: A Laboratory Manual. 2nd ed. Cold Spring Harbor Laboratory Press, Cold Spring Harbor, N.Y., U.S.A.
Schwartz, H. F., and Mohan, S. K. 2008. Compendium of onion and garlic diseases and pests, 2nd Ed. American Phytopathological Society, St. Paul, MN, U.S.A.

Schwartz, H. F., and Otto, K. 2000. First report of a leaf blight and bulb decay of onion by Pantoea ananatis in Colorado. Plant Dis. 84:808.

Shyntum, D. Y., Theron, J., Venter, S. N., Moleleki, L. N., Toth, I. K., and Coutinho, T. A. 2015. Pantoea ananatis utilizes a type VI secretion system for pathogenesis and bacterial competition. Mol. Plant-Microbe Interact 28:420-431.

Stumpf, S., Kvitko, B., Gitaitis, R., and Dutta, B. 2018. Isolation and characterization of novel Pantoea stewartii subsp. indologenes strains exhibiting center rot in onion. Plant Dis. 102:727-733.

Vernikos, G. S., and Parkhill, J. 2006. Interpolated variable order motifs for identification of horizontally acquired DNA: Revisiting the Salmonella pathogenicity islands. Bioinformatics 22:2196-2203.

Walterson, A. M., and Stavrinides, J. 2015. Pantoea: Insights into a highly versatile and diverse genus within the Enterobacteriaceae. FEMS Microbiol. Rev. 39:968-984.

Weinthal, D. M., Barash, I., Panijel, M., Valinsky, L., Gaba, V., and Manulis-Sasson, S. 2007. Distribution and replication of the pathogenicity plasmid pPATH in diverse populations of the gall-forming bacterium Pantoea agglomerans. Appl. Environ. Microbiol. 73:7552-7561.

Weller-Stuart, T., Chan, W. Y., Coutinho, T. A., Venter, S. N., Smits, T. H., Duffy, B., Goszczynska, T., Cowan, D. A., and de Maayer, P. 2014. Draft genome sequences of the onion center rot pathogen Pantoea ananatis PA4 and maize brown stalk rot pathogen P. ananatis BD442. Genome Announc. 2:e00750-14.

Weller-Stuart, T., Toth, I., De Maayer, P., and Coutinho, T. 2017. Swimming and twitching motility are essential for attachment and virulence of Pantoea ananatis in onion seedlings. Mol. Plant Pathol. 18:734-745.

Yu, X., Doroghazi, J. R., Janga, S. C., Zhang, J. K., Circello, B., Griffin, B. M., Labeda, D. P., and Metcalf, W. W. 2013. Diversity and abundance of phosphonate biosynthetic genes in nature. Proc. Natl. Acad. Sci. U.S. A. 110:20759-20764

Zaid, A. M., Bonasera, J. M., and Beer, S. V. 2012. OEM-A new medium for rapid isolation of onion-pathogenic and onion-associated bacteria. J. Microbiol. Methods 91:520-526.

\section{AUTHOR-RECOMMENDED INTERNET RESOURCE}

BLAST website: https://blast.ncbi.nlm.nih.gov 